\title{
MEMBERS OF THE
}

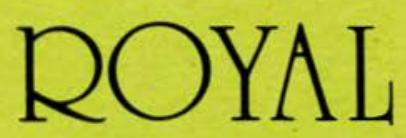

SHAKESPEARE
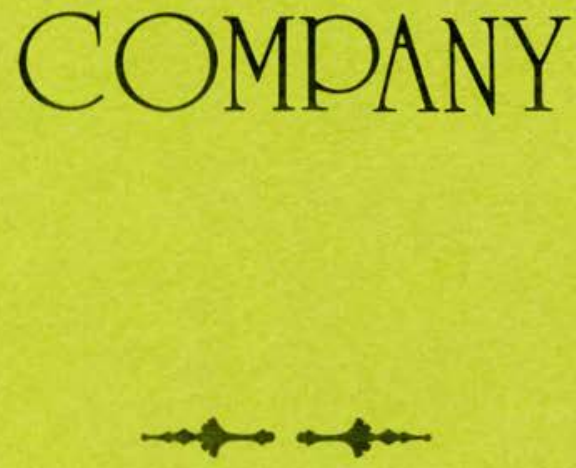

KENNEDY THEATRE

MARCH 4-5-6, 1976 
Founded in 1879, the Royal Shakespeare Theatre was called the Shakespeare Memorial Theatre until 1961 when it was incorporated under Royal Charter with the Queen as Patron. The Royal Shakespeare Company are divided for most of each year, playing concurrently at the Royal Shakespeare Theatre in Stratford-upon-Avon, Shakespeare's birthplace, and at the Aldwych Theatre in London. Shakespeare is the Company's main concern, but performances of other classical and modern plays bridge the gap between Shakespeare and the contemporary theatre.

The members of the Royal Shakespeare Company appearing this evening are not only talented actors, directors and musicians, but they are also gifted teachers. During this week in Honolulu, they have been conducting workshops, holding seminars and giving lectures at the East-West Center, at the University of Hawaii and in the Honolulu community.

During the last two years, the Culture Learning Institute has presented exhibitions of paintings from the Republic of China and from Korea, a demonstration of the Martial Arts of Japan, a lecture and demonstration of baton-twirling as practiced in the United States, readings of Indonesian and Malaysian poetry and performances of classical Chinese Opera, Balinese Puppetry, Thai music, Indonesian, Malaysian and Australian Aboriginal Dance and Jazz--East and West. These presentations have given us invaluable insights into the creative expressions and values of different cultures.

We are fortunate to have with us this week a distinguished group of artists who will remind us of some of the riches of the Elizabethan theatre and of the British cultural heritage.

\author{
Verner C. Bickley \\ Director \\ East-West Culture Learning Institute
}


BERNARD LLOYD is a graduate of Keele University, and studied at the Royal Academy of Dramatic Art. He has devoted half his professional life to the Royal Shakespeare Company, both in Stratfordupon-Avon and London, in a variety of roles. He recently completed a tour of London Assurance, in which he played Dazzle, which included Detroit, Washington and New York. He has also performed in several musicals, including the London production of 1776 .

PATRICK STEWART trained at Bristol's Old Vic Theatre School and joined the RSC in 1966, where he has appeared in such plays as Henry IV, Henry V , Hamlet, Revengers' Tragedy, and The Taming of the Shrew. He was made an Associate Artist in 1968. In the United States he has appeared on Broadway in Peter Brooks production of Midsummer Night's Dream, and last year played Eilert Loevborg opposite Glenda Jackson in Hedda Gabler in London, Los Angeles, and Washington, D.C., and later in the film of that production. He has worked frequently in television serials and films.

You will want to be sure to see these performances:

- OUR TOWN -- Thonton Wilders'American classic now at the Honolulu Community Theatre.

- THE GLASS MENAGERIE -- Many consider it to be Tennessee Williams best. Kennedy Theatre, March 19, 20, 21, 25, 26, 27 and 28, 1976.

- HAMLET -- Starring Randy Kim, returning to Honolulu after triumphant performances in New York and San Francisco. Leeward Community College Theatre, Opening March 19, 1976. 
THE EAST-WEST CENTER is a national educational institution established in Hawaii by the U.S. Congress in $\mathbf{1 9 6 0}$ to "promote better relations and understanding between the United States and the nations of Asia and the Pacific through cooperative sludy, training and research."

Each year the East-West Center brings together more than $\mathbf{1 . 5 0 0}$ men and women from the many nations and cultures of these regions. They work and study together while exchanging ideas and experiences in cooperative programs seeking solutions to important problems of mutual concern to East and West. For each participant from the United States in Center programs, two participants are sought from the more than 60 countries and territories in Asia and the Pacific area.

Five institutes with-international, interdisciplinary academic and professional staffs conduct the East-West Center's problem oriented programs. East-West areas on which Center programs are focused include communication acruss national barriers, culture and language learning, food systems, population dynamics, and technological adaptation in developmental processes aimed at improving the quality of life. Each year the Center awards a limited number of Open Grants for graduate degree education and innovative research by Senior Fellows in areas not encompassed by institute programs.

The Center is directed by the Board of Governors of a public, non-profit educational corporation-known as "The Center for Cultural and Technical Interchange Between East and West, Inc."-created by the Hawaii State Legislature in 1375. The U.S. Congress provides basic funding for Center programs and a variety of scholarships, fellowships, internships and other awards. Additional cost-sharing of programs and participants is worked out with Asian/Pacific governments, regional agencies, private enterprise and foundations. The Center is siluated on land adjacent to and provided by the University of Hawaii, which conducts classes and grants degrees for degree-seeking East-West Center students who also are involved in the Center's problem-oriented programs. 


\title{
F The EAST-WEST CENTER \\ CULTURE LEARNING INSTITUTE \\ in cooperation with \\ U.H. Department of Drama and Theatre
}

\author{
presents
}

\section{Members of the Royal Shakespeare Company}

\section{Tony Church \\ Lisa Harrow}

Patrick Stewart

\author{
in \\ HE THAT PLAYS THE KING \\ and \\ SHALL I COMPARE THEE
}

Charles Keating

Bernard Lloyd

The appearance of the actors was arranged by the Center for Dramatic Teaching, University of California, Santa Barbara. 
HE THAT PLAYS THE KING

March 4 and 5, 1976

$$
\text { Part I -- The Histories }
$$

Henry $V$

Richard II

Henry IV Part 2

Richard III

Intermission

Part II -- The Tragedies

Macbeth

King Lear

King John

Hamlet

Program compiled by Ian Richardson Music composed by Guy Woolfenden

NOTICE: Smoking is not allowed in the Auditorium nor may photographs or recordings be made during the performance. 
Part I

Sonnet 130

Troilus

Don Armado

Valentine

Proteus

Who is Silvia?

Hermia \& Lysander

Berowne

Mercutio

It Was a Lover $\&$ his Lass Touchstone and Audrey

It Was a Lover \& his Lass

(continued)

Rosalind and Orlando

Launce and $\mathrm{Crab}$

We Shall No More to Sea

Intermission

Part II

Sonnet 116

Orsino and Viola

Sonnet 138

Petruchio

Benedick

Sonnet 129

Helen, Paris and Pandarus

Cloten with Pisanio

Leontes

Emilia

Silence's Songs

Anfidius and Coriolanus

Ventidius on Cleopatra

Antony and Cleopatra

Pyramus and Thisbe

King Lear

O Mistress Mine
"My mistress' eyes are nothing like the sun"

Troilus \& Cressida

Love's Labours Lost

Two Gentlemen of Verona

Midsummer Night's Dream

Love's Labours Lost

Romeo and Juliet

As You Like It

Two Gentlemen of Verona

The Tempest

"Let me not to the marriage of true minds"

Twelfth Night

"When my love swears that she is made of truth"

The Taming of the Shrew Much Ado About Nothing "The expense of spirit in

a waste of shame?

Troilas and Cressida

Cymbeline

A Winter's Tale

Othello

Henry IV, 2

Coriolanus

Antony and Cleopatra

A Midsummer Night's Dream

King Lear

Twelfth Night

Program compiled by Ian Richardson and the cast

Musical arrangement by Charles Keating and the cast 
Part I

Sonnet 130

Troilus

Don Armado

Valentine

Proteus

Who is Silvia?

Hermia \& Lysander

Berowne

Mercutio

It Was a Lover $\&$ his Lass Touchstone and Audrey

It Was a Lover \& his Lass (continued)

Rosalind and Orlando

Launce and $\mathrm{Crab}$

We Shall No More to Sea

\section{Intermission}

Part II

Sonnet 116

Orsino and Viola

Sonnet 138

Petruchio

Benedick

Sonnet 129

Helen, Paris and Pandarus Cloten with Pisanio

Leontes

Emilia

Silence's Songs

Anfidius and Coriolanus

Ventidius on Cleopatra

Antony and Cleopatra

Pyramus and Thisbe

King Lear

O Mistress Mine
"My mistress' eyes are nothing like the sun"

Troilus \& Cressida

Love's Labours Lost

Two Gentlemen of Verona

Midsummer Night's Dream

Love's Labours Lost

Romeo and Juliet

As You Like It

Two Gentlemen of Verona

The Tempest

"Let me not to the marriage of true minds"

Twelfth Night

"When my love swears that she

is made of truth"

The Taming of the Shrew

Much Ado About Nothing

"The expense of spirit in

a waste of shame?

Troilas and Cressida

Cymbeline

A Winter's Tale

Othello

Henry IV, 2

Coriolanus

Antony and Cleopatra

A Midsummer Night's Dream

King Lear

Twelfth Night

Program compiled by Ian Richardson and the cast

Musical arrangement by Charles Keating and the cast 
TONY CHURCH is well known to RSC audiences for his numerous roles including Antigonus in The Winter's Taie, Hortensio in The Taming of the Shrew, Belarious in Cymbeline, Quince in A Midsummer Night's Dream, Cornwall in King Lear, Flavius in Timon of Athens, Polonius in Hamlet, the title role in both parts of Henry IV, Sir Toby in Twelfth Night, Antonio in The Merchant of Venice, Third Knight/Tempter in Murder In the Cathedral, Kostylyov in The Lower Depths, Friar Laurence in Romeo and Juliet, John of Gaunt in Richard II, Duke Senior in As You Like It, Suslov in Summerfolk, and Don Armado in Love's Labour's Lost.

The first director of the Northcott Theatre, Exeter, Mr. Church played leading roles in The Merchant of Venice; The Homecoming; Wesley--A Man Against His Age; and Soldiers. During his three years at Northcott $(1967-70)$ the distinguished artist directed Hamlet, Twelfth Night and The Boy Friend.

LISA HARROW came to England from her native New Zealand in 1966, where she entered the Royal Academy of Dramatic Art. She joined the RSC in 1969, appearing in such roles as Olivia in Twelfth Night, the Queen in Richard II, Natasha in Lower Depths, Desdemona in Othello, and The Hollow Crown. She has also appeared in the films All Creatures Great and Small and All Things Bright and Beautiful, as well as The Devil is a Woman, which she made in Rome. Last month Ms. Harrow received the British Variety Club Award as the Most Promising New Artist in film.

CHARLES KEATING's work for the Royal Shakespeare Company includes Cymbeline, Lear, Richard II, As You Like It, The Taming of the Shrew, and The Marquis of Keith. He also performed in the opening productions of the Bankside Globe Theatre in London, and was invited to join the Crucible Theatre, Sheffield, for their opening season as Actor/Director. Mr. Keating's television credits include the series Crown Court, Dream of Living, and The Life and Death of Penelope. In the United States he has performed in night clubs and on the concert recital platform, and has had seasons in Cleveland and Boston, and the Tyrone Guthrie Theatre in Minneapolis. 